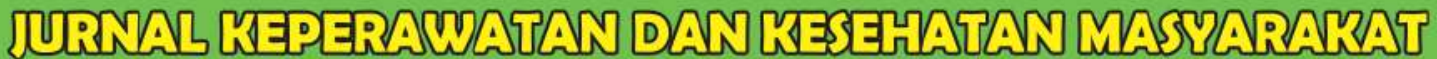 CENTDEZTA UYPANA
}

Peningkatan Pengetahuan dan Sikap Remaja tentang Kesehatan Reproduksi Melalui Pendidikan Kesehatan Berupa Aplikasi Layanan Keperawatan Kesehatan Reproduksi Remaja (Lawan Roma) di SMP Wilayah Kerja Puskesmas Bawen Kabupaten Semarang Tina Mawardika, Dian Indriani, Liyanovitasari

Pengaruh Terapi Senam Kaki terhadap Sensitivitas dan Perfusi Jaringan Perifer Pasien Diabetes Melitus di Ruangan Instalasi Rawat Inap RSUD Prof. Dr. W. Z. Johannes Kupang

Ferdinandus Suban Hoda, Serly Sani Mahoklory, Okto Elferson Lusi

Gambaran Caring Perawat dalam Memberikan Asuhan Keperawatan di Ruang Intensive Care Unit (ICU) RSUD RAA Soewondo Pati

Emma Setiyo Wulan, Wiwin Nur Rohmah

Inkontinensia Urin pada Lansia Perempuan

Suyanto

Pengaruh Relaksasi Otot Progresif terhadap Kualitas Tidur pada Perempuan Menopause Steffy Putri Amanda, Sri Rejeki, Dwi Susilawati

Pengaruh Akupresur dan Shaker Exercise terhadap Kemampuan Menelan Pasien Stroke Akut dengan Disfagia

Dewi Siyamti, Dwi Pudjonarko, Mardiyono Mardiyono

Kajian Komitmen dan Struktur Birokrasi pada Implementasi Kebijakan Kapitasi Berbasis Komitmen Pelayanan Badan Penyelenggara Jaminan Sosial Kesehatan (KBKBPJS) Kesehatan di Kota Semarang

Arif Sofyandi,Chriswardani Suryawati,Hardi Warsono

Studi Kasus Interaksi Sosial Orang dengan HIV/AIDS (ODHA) Terhadap Stigma

Nila Putri Purwandari, Andrew Johan, Untung Sujianto

Sistem Pelaporan Insiden Keselamatan Pasien di sebuah Rumah Sakit Swasta di Kudus Endang Sri Lestari, Luki Dwiantoro, Hanifa Maher Denny

Implementasi Sistem Penanggulangan Gawat Darurat Terpadu K119 (SPGDT K119) di Kabupaten Kudus

Amad Mochamad, Septo Pawelas Arso, Yuliani Setyaningsih

\section{SEKOLAH TINGGI ILMU KESEHATAN CENDEKIA UTAMA KUDUS}




\title{
JURNAL KEPERAWATAN DAN KESEHATAN MASYARAKAT CENDEKIA UTAMA
}

\author{
Editor In Chief \\ Ns.Sri Hartini, S.Kep, M.Kes , \\ STIKES Cendekia Utama Kudus, Indonesia
}

\section{Editor Board}

Eko Prasetyo, S.KM, M.Kes, STIKES Cendekia Utama Kudus, Indonesia David Laksamana Caesar, S.KM., M.Kes, STIKES Cendekia Utama Kudus, Indonesia Ns. Heriyanti Widyaningsih, M.Kep, STIKES Cendekia Utama Kudus, Indonesia Ns.Anita Dyah Listyarini, M.Kep,Sp.Kep.Kom,STIKES Cendekia Utama Kudus, Indonesia

\section{Reviewer}

Dr. Sri Rejeki, M.Kep, Sp.Kep. Mat, Universitas Muhammadiyah Semarang, Indonesia Dr. dr. Mahalul Azam, M.Kes., Universitas Negeri Semarang, Indonesia Ns.Wahyu Hidayati, M.Kep, Sp.K.M.B, Universitas Diponegoro Semarang, Indonesia

\section{English Language Editor}

Ns.Sri Hindriyastuti, M.N, STIKES Cendekia Utama Kudus, Indonesia

\section{IT Support}

Susilo Restu Wahyuno, S.Kom, STIKES Cendekia Utama Kudus, Indonesia

\section{Penerbit}

STIKES Cendekia Utama Kudus

Alamat
Jalan Lingkar Raya Kudus - Pati KM.5 Jepang Mejobo Kudus 59381
Telp. (0291) 4248655, 4248656 Fax. (0291) 4248651
Website :http://jurnal.stikescendekiautamakudus.ac.id/index.php/stikes
Email :jurnal@ stikescendekiautamakudus.ac.id

Jurnal Keperawatan dan Kesehatan Masyarakat "Cendekia Utama" merupakan Jurnal Ilmiah dalam bidang Ilmu Keperawatan dan Kesehatan Masyarakat yang diterbitkan oleh STIKES Cendekia Utama Kudus secara berkala dua kali dalam satu tahun. 


\section{DAFTAR ISI}

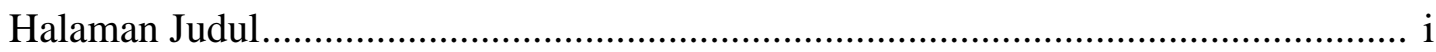

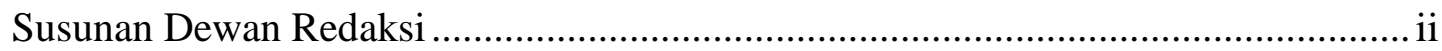

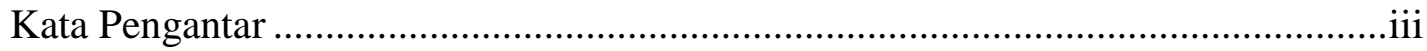

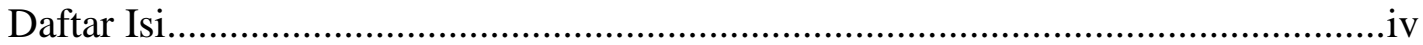

Peningkatan Pengetahuan dan Sikap Remaja tentang Kesehatan Reproduksi Melalui Pendidikan Kesehatan Berupa Aplikasi Layanan Keperawatan Kesehatan Reproduksi Remaja (Lawan Roma) di SMP Wilayah Kerja Puskesmas Bawen Kabupaten Semarang 99

Pengaruh Terapi Senam Kaki terhadap Sensitivitas dan Perfusi Jaringan Perifer Pasien Diabetes Melitus di Ruangan Instalasi Rawat Inap RSUD Prof. Dr. W. Z. Johannes Kupang

Gambaran Caring Perawat dalam Memberikan Asuhan Keperawatan di Ruang Intensive Care Unit (ICU) RSUD RAA Soewondo Pati 120

Inkontinensia Urin pada Lansia Perempuan 127

Pengaruh Relaksasi Otot Progresif terhadap Kualitas Tidur pada Perempuan Menopause

Pengaruh Akupresur dan Shaker Exerciseterhadap Kemampuan Menelan Pasien Stroke Akut dengan Disfagia

Kajian Komitmen dan Struktur Birokrasi pada Implementasi Kebijakan Kapitasi Berbasis Komitmen Pelayanan Badan Penyelenggara Jaminan Sosial Kesehatan (KBK-BPJS) Kesehatan di Kota Semarang

Studi Kasus Interaksi Sosial Orang dengan HIV/AIDS (ODHA) Terhadap

Stigma

Sistem Pelaporan Insiden Keselamatan Pasien disebuah Rumah Sakit Swasta di Kudus

Implementasi Sistem Penanggulangan Gawat Darurat Terpadu K119 (SPGDT K119)

Di Kabupaten Kudus

Pedoman Penulisan Naskah 194 


\title{
GAMBARAN CARING PERAWAT DALAM MEMBERIKAN ASUHAN KEPERAWATAN DI RUANG INTENSIVE CARE UNIT (ICU) RSUD RAA SOEWONDO PATI
}

\author{
Emma Setiyo Wulan ${ }^{1}$,Wiwin Nur Rohmah ${ }^{2}$ \\ 1,2Program Studi S1 Ilmu Keperawatan STIKES Cendekia Utama Kudus \\ Email: emmawulan8@gmail.com
}

\begin{abstract}
ABSTRAK
Intensive Care Unit (ICU) adalah ruang rawat rumah sakit dengan staf dan perlengkapan khusus ditunjukan untuk mengelola pasien dengan penyakit, trauma atau komplikasi yang mengancam jiwa. Di ruang Intensive Care Unit (ICU) juga telah menyediakan sarana dan prasarana serta peralatan khusus dengan menggunakan keterampilan staf medik dan perawat yang berpengalaman dalam memberikan asuhan keperawatan secara intensif.Pelayanan rumah sakit hakekatnya adalah memenuhi kebutuhan dan tuntutan masyarakat selaku pemakai jasa pelayanan kesehatan. Bila kebutuhan mayarakat ( pasien) belum terpenuhi, misalsikapperawat yang dinilaikurangcaringdengan pasien sehingga pasien akan merasa kurang puas. Perawatbertanggungjawabterhadappelayanandanasuhan keperawatan yang diberikan kepada pasien.Teknik pengambilan sampel dilakukan dengan teknik accidental sampling yaitu teknik pengambilan sampel dengan mengambil responden atau kasus yang kebetulan ada atau tersedia. Sampel dalam penelitian iniadalahsejumlah 20perawat.Caring perawat di ruang ICU (Intensive Care Unit) RSUD RAA Soewondo Pati Tahun 2017 sebagian besar baik sebanyak 15 orang (75\%), caring cukup 3 orang (15\%) sedangkan yang caring perawat kurang sebanyak 2 orang $(10 \%)$.Caring perawat di ruang ICU (Intensive Care Unit) dibutuhkan dalam memberikan asuhan keperawatan.
\end{abstract}

Kata Kunci : Caring perawat, ICU, Asuhan Keperawatan

\begin{abstract}
Intensive Care Unit (ICU) is hospital wards with staff and special equipment shown for managing patients with internal disease, trauma or life threatening complications. In room Intensive Care Unit (ICU) also has provided facilities and infrastructur as well as special equipment. If needs of the community has not been met for example the attitude of the nurse who assessed less caring with the patient so that patients will feel less satisfied. The nurse responsible for the service and nursing care given to the patient the sampling.Sampling technique is done by technique accidental sampling namely the sampling technique by taking the respondent or typical of a coincidence that there or avaible.Hospital service is essentially fulfilling the needs and demands of the community as users of health services. Caring nurse in room (Intensive Care Unit) RSUD RAA Soewondo Pati year 2017 mostly good as many as 15 people (75\%), caring quite as much 3 people (15\%), while the caring nurse less 2 people (10\%). Sample in this study were 20 nurses. Caring nurse (Intensive Care Unit) RSUD RAA Soewondo is needed in providing nursing care.
\end{abstract}

Keywords : Caring nurse, ICU, Nursing care. 


\section{PENDAHULUAN}

Intensive Care Unit (ICU) adalah suatu bagian dari rumah sakit yang mandiri, dengan staf yang terlatih dan perlengkapan khusus yang ditujukan untuk observasi, perawatan dan memberikan terapi untuk pasien-pasien yang menderita penyakit akut, cedera atau penyakit lain yang mengancam nyawa (Kemenkes, 2011). Perlakuan terhadap pasien di Intensive Care Unit (ICU) agak berbeda dengan pasien dirawat inap biasa, karena pasien Intensive Care Unit (ICU) dapat dikatakan ada ketergantungan yang sangat tinggi terhadap perawat dan dokternya. Diruang Intensive Care Unit (ICU) pasien yang sakit kritis atau kehilangan kesadaran, sehingga segala sesuatu yang terjadi pada diri pasien hanya dapat diketahui melalui monitoring dan rekording yang baik dan teratur. Perubahan yang terjadi harus dianalisis secara cermat untuk mendapatkan tindakan atau pengobatan yang tepat (Musliha, 2012).

Pada dasarnya pasien yang dirawat di Intensive Care Unit (ICU) adalah pasien dengan gangguan akut yang diharapkan reversibel (pulih kembali) mengingat Intensive Care Unit (ICU) adalah tempat perawatan yang memerlukan biyaya yang tinggi dilihat dari segi peralatan dan tenaga (yang khusus). Kebutuhan pelayanan pasien di ruang Intensive Care Unit (ICU) adalah tindakan resusitasi jangka panjang yang meliputi dukungan hidup untuk fungsi- fungsi vital seperti airway (fungsi jalan napas), breathing (fungsi pernapasan), circulation (fungsi sirkulasi), brain (fungsi otak) dan fungsi organ lain, disertai dengan diagnosis dan terapi (Kemenkes, 2011).

Dengan alasan penanganan untuk pasien dalam kondisi kritis maka diperlukan perawat yang berpengalaman/ yang sudah bersertifikat Intensive Care Unit (ICU) untuk merawat pasien-pasien yang dalam kondisi kritis dalam memberikan asuhan keperawatan pada pasien di ruang Intensive Care Unit (ICU) perawat memiliki beberapa tugas pokok. Tugas pokok perawat tersebut dalam mengelola pelayanan dan asuhan keperawatan secara komprehensif meriputi pengkajian, diagnosis keperawatan, perencanaan, tindakan keperawatan pada pasien Intensive Care Unit (1CU). Uraian tugas perawat yaitu bertindak sebagai anggota tim di semua jenis pelayanan, melaksanakan semua program terapi yang di jadwalkan perawatan sesuai rencana keperawatan, melaksanakan re-evaruasi pasien dengan mengunsurkan program keperawatan selanjutnya bagi pasien, perawat juga bertangggung jawab atas pelaksanaan program perawatan Intensive Care Unit (ICU) kepada koordinator pelayanan Intensive Care Unit (ICU), selain itu, perawat harus benar-benar menjaga pasien dengan baik, karena selain tanggung jawabperawatkepadacoordinator,jugamerupakanamanah dari keluarga pasien untuk selalu memberikan perawatan terbaik untuk pasien (Kemenkes, 2011).

Perlakuan terhadap keluarga pasien di ruang Intensive CareUnit(ICU) tidak sama dengan perlakuan kepada kelurga pasien yang diruang lain, karena pasien tidak dapat ditunggu oleh keluarga didalam ruangIntensive Care(ICU). jadi, diperlukan komunikasi yang baik antara dokter/ perawatIntensive Care Unit(ICU) dengan keluarga secara teratur dan konsisten. Harus dijelaskan secara jelas keadaan sebenarnya dari pasien dengan bahasa sederhana saat masuk atau bilamana ada perubahan keadaan pasien. Bila keadaan pasien dalam sakaratul maut, keluarga dapat dipersilahkan masuk untuk melakukan ritual agama tertentu. Keluarga yang penuh kecemasan takut kehilangan keluarga, penolakan terhadap 
penyakit yang menimpa, rasa tidak percaya, rasa berdosa, rasa marah ini perlu mendapatkan pendekatan yang baik dari perawat Intensive Care Unit (ICU) (Musliha, 2012).

Proses pemberian asuhan keperawatan yang dilakukan perawat profesional yaitu meliputi pengetahuan dan praktik keperawatan.Perilaku caring perawat terdiri dari elemen-elemen yang terdapat dalam 10 faktor karatif yaitu nilai-nilai kemanusiaan dan altruistik, keyakinan dan harapan, peka pada diri sendiri dan orang lain, membantu menumbuhkan kepercayaan, pengekspresian peran positif dan negatif, proses pemecahan masalah perawatan secara sistematis, pembelajaran secara interpersonal, dukungan fisik, mental, sosial, spiritual, memenuhi kebutuhan manusia dengan penuh penghargaan, dan eksistensi fenomena kekuatan spiritual (Asmadi, 2008). Kekuatan pendorong utama yang memotivasi seseorang untuk sembuh adalah caring perawat. Seorang perawat harus memiliki sikap caring dalam memberikan asuhan keperawatan yang bermutu terhadap semua pasiennya, dengan caring yang diberikan oleh perawat otomatis akan membuat perasaan pasien senang, puas dan memotivasi pasien untuk cepat sembuh. Akan tetapi pada kenyataannya hingga saat ini perawat masih terus melaksanakan tugas keperawatan yang hanya berorientasi pada proses penyakit serta tindakan medis saja (Marrison \& Burnard 2009). Pasien yang dirawat di rumah sakit akan mendapatkan asuhan keperawatan dengan penuh perhatian. Bentuk perhatian dan kepedulian perawat yaitu kehadiran perawat sebagai helper (Asmadi, 2008).

Berdasarkan hasil studi pendahuluan yang dilakukan oleh peneliti di ruang intensive care unit(ICU) RSUD RAA Soewondo Pati didapatkan gambaran tingkat caring perawat belum maksimal pernyataan ini didukung dari hasil wawancara peneliti dengan kepala ruang dan lima perawat di ruang intensive care unit RSUD RAA Soewondo Pati bahwa perawatkurangmemberikankepercayaan padapasienuntuk dapatsembuh kembali, pernyataan itu didukung oleh tiga perawat yang menjawab tidak, perawat kurangmemberikanharapanapabila pasiendirawat dengan baik maka kondisi pasienakanlebihbaik, pernyataan itu juga di kuatkan oleh dua perawat yang menjawab tidak, perawat hanya menanyakan/ melihat keluhan pasien pada saat asesment.

Hasil data survey kepuasan masyarakat yang diperoleh dari Humas RSUD RAA Soewondo Pati pada periode Januari-Maret 2017 dari 150 responden di ruangICU didapatkan total indeks kepuasan masyarakat adalah 92\%. Berdasarkan uraian tersebut dan dikuatkan pula oleh jurnal penelitian yang dilakukan oleh Sunardi (2014) yang berjudul analisis prilaku caring perawat pelaksana di Rumah Sakit Wisma Harapan Malang, dalam pemberian asuhan keperawatan pada pasien, perawat sering mendapat kritikan akan terjadinya perilaku yang masih belum dekatdenganpasien, kurangresponsifterhadappermasalahanpasien, dan berbagai stigma negatif lainnya dan hasil penelitian menunjukan level perilaku caring perawat yaitu sebesar $83,6 \%$.

\section{METODE PENELITIAN}

Penelitian ini adalah penelitian kuantitatif dengan teknik pengambilan sampel dilakukan dengan teknik accidental sampling yaitu teknik pengambilan sampel dengan mengambil responden atau kasus yang kebetulan ada atau tersedia. Sampel adalah sebagian dari populasi yang mewakili suatu populasi (Saryono, 2010). Disini peneliti mengambil sampel sebanyak 20 perawat di ruang 
Intensive Care Unit (ICU) RSUD RAA. Soewondo Pati. Penelitian ini dilakukan pada tanggal 11 -18 Juli 2017.Karakterisik responden dalam penelitian ini adalah perawat yang jenjang pendidikannya minimal diploma, perawat yang masa kerjanya lebih dari 1 tahun. Instrumen dalam penelitian ini menggunakan lembar observasi yang berisi 20 pertanyaan.

\section{HASIL DAN PEMBAHASAN \\ Hasil}

\section{Karakteristik responden}

Karakteristik responden meliputi, jenis kelamin, pendidikan dan masa kerja perawat di ruang ICU (Intensive Care Unit) RSUD RAA Soewondo Pati Tahun 2017, sebagai berikut :

Tabel 1. Jenis Kelamin, Pendidikan dan Masa kerja Perawat di Ruang ICU (Intensive Care Unit) RSUD RAA Soewondo Pati Tahun 2017

\begin{tabular}{clcc}
\hline No & \multicolumn{1}{c}{ Karaketrsitik } & Frequency & Percent \\
\hline 1 & Jenis Kelamin & 7 & 35.0 \\
& Laki laki & 13 & 65.0 \\
& Perempuan & & \\
& Pendidikan & 16 & 80.0 \\
& Diploma 3 perawatan & 1 & 5.0 \\
& S1 keperawatan & 3 & 15.0 \\
& Ners & & \\
& Masa kerja & 3 & 15.0 \\
& 1-4 tahun & 15 & 75.0 \\
& 5-8 tahun & 2 & 10.0 \\
\hline & $\geq 9$ tahun & 20 & 100.0 \\
\hline
\end{tabular}

Tabel 1 diketahui bahwa jenis kelamin perawat di ruang ICU (Intensive Care Unit) RSUD RAA Soewondo Pati Tahun 2017 sebagian besar perempuan sebanyak 13 orang dan yang laki laki sebanyak 7 orang. Pendidikan perawat di ruang ICU (Intensive Care Unit) RSUD RAA Soewondo Pati Tahun 2017 sebagian besar D3 keperawatan sebanyak 16 orang (80\%) sedangkan pendidikan S1 keperawatan sebanyak 1 orang (5\%). Ners sebanyak 3 orang (15\%). Masa kerja perawat di ruang ICU (Intensive Care Unit) RSUD RAA Soewondo Pati Tahun 2017 sebagian besar mempunyai masa kerja 5-8 tahun sebanyak 15 orang $(75 \%)$ dan paling sedikitmempunyaimasakerja $\geq 9$ tahun sebanyak 2 orang $(10 \%)$.

\section{Gambaran Caring Perawat}

Gambaran caring perawat di ruang ICU (Intensive Care Unit) RSUD RAA Soewondo Pati Tahun 2017, disajikan pada Tabel 4.3 berikut ini :

Tabel 2. Gambaran Caring Perawat di Ruang ICU (Intensive Care Unit) RSUD RAA. Soewondo Pati Tahun 2017

\begin{tabular}{clcc}
\hline No & \multicolumn{1}{c}{ Caring Perawat } & Frequency & Percent \\
\hline 1 & Kurang & 2 & 10.0 \\
2 & Cukup & 3 & 15.0 \\
3 & Baik & 15 & 75.0 \\
\hline & Jumlah & 20 & 100.0 \\
\hline
\end{tabular}


Tabel 4.3 diketahui caring perawat di ruang ICU (Intensive Care Unit) RSUD.RAA. Soewondo Pati Tahun 2017 sebagian besar baik sebanyak 15 orang (75\%) yang tergolong cukup sebanyak 3 orang (15\%) sedangkan yang caring perawat kurang sebanyak 2 orang (10\%).

\section{Pembahasan.}

Hasil penelitian diketahui bahwa caring perawat di ruang ICU (Intensive Care Unit) RSUD RAA Soewondo Pati Tahun 2017 sebagian besar baik sebanyak 15 orang $(75 \%)$ perawat yang caring nya cukup sebanyak 3 orang (15\%) sedangkan yang caring perawat kurang sebanyak 2 orang (10\%) Penelitian ini didukung oleh jurnal penelitian yang dilakukan oleh Listianingsih (2012) yang berjudul hubungan perilaku caring perawat dengan kepuasan pasien false emergency di Unit Gawat Darurat Rumah Sakit Cahya Kawaluyan. Hasil penelitian tersebut diperoleh $60,2 \%$ responden mengatakan perilaku caring perawat baik dan 59,2\% mengatakan puas.Hasil lain dariwawancara peneliti dengan 6 dari 10 pasien false emergency mengatakan perawat berbicara dengan pasien jika ada yang perlu ditanya saja, tidak memperkenalkan diri, tidak mengucapkan salam saat bertemu, perawat tidak menatap pasien saat berbicara, pasien cenderung menunggu lama, dan perawat kurangtanggapterhadappasien.

Caring perawat di ruang ICU (Intensive Care Unit) RSUD RAA Soewondo Pati sebagian besar baik sebanyak 15 orang (75\%). Mungkin dikarenakan adanya pengaruhperawat yang selalu diberikan motivasi, ada juga supervisi dan breving bahwa dalam memberikan pelayanan kepada pasien harus memenuhi visi misi rumah sakit dan selalu bekerja sesuai dengan Standar Operasional Prosedur. Perawat di Ruang ICU (Intensive Care Unit) sebelum memulai bekerja ketuatimmemberikanbreaving,memberikanpenekanankepada kondisi pasien yang dirawat, berdiskusi dan memberikan feed bak kepada perawat yang melakukan perawatan.

Pernyataan tersebut didukung dari jurnal penelitian yang dilakukan oleh Natasia, Andriani dkk (2014) jurnal penelitian yang berjudul Hubungan Antara Faktor Motivasi dan Supervisi Dengan Kinerja Perawat Dalam Pendokumentasian Discharge Planning di RSUD Gambiran Kota Kediri, yaitu sebesar 85\% dokumentasi discharge planning yang tidak lengkap dilakukan oleh perawat dengan motivasi rendah dan hanya $15 \%$ yang didokumentasikan dengan lengkap. Sebesar 74\% dokumentasi discharge planning yang lengkap dilakukan oleh perawat dengan motivasi tinggi dan hanya $26 \%$ dokumentasi tidak lengkap. Hasil analisis hubungan antara motivasi dengan kinerja perawat dalam pendokumentasian discharge planning diperoleh nilai $\mathrm{p}$ value $<0,05$ yang artinya ada hubungan yang bermakna antara faktor motivasi perawat dengan pendokumentasian discharge planning. Hasil uji analisis menunjukkan ada hubungan antara faktor motivasi dan supervisi dengan kinerja perawat dalam pendokumentasian discharge planning. Jadi jika ada supervisi akan lebih baik.

Faktor yang mendukung caring perawat di ruang ICU (Intensive Care Unit) RSUD RAA Soewondo Pati sebagian besar baik sebanyak 15 orang (75\%) adalah pendidikan perawat S1 dan Ners sebanyak 20\%. Pendidikan yang tinggi perawatakan melakukan analisis data berdasarkan kenyataan di lapangan dan menentukan pemecahan masalah berdasarkan prioritas masalah. Menurut Wawan dan Dewi (2010) Pendidikan adalah bimbingan yang diberikan seseorang terhadap 
perkembangan orang lain menuju cita-cita yang menentukan untuk mengisi kehidupan untuk mencapai keselamatan dan kebahagiaan. Pendidikan diperlukan untuk mendapatkan informasi misalnya hal-hal yang menunjang kesehatan sehingga dapat meningkatkan kualitas hidup. Pendidikan dapat mempengaruhi seseorang termasuk juga perilaku seseorang akan pola hidup terutama dalam memotivasi untuk bersikap dan berperan dalam pembangunan.

Caring perawat di ruang ICU (Intensive Care Unit) RSUD RAA Soewondo Pati ada yang kurang sebanyak 2 orang (10\%), mungkin faktor penyebab caringyang kurang yaitu tekanan mental psikologis dari perawat sangat tinggi karena berhubungan dengan perawatan yang intensif dan pasien sangat dekat dengan kematian. Hal ini didukung oleh jurnal penelitian yang dilakukan Suhartati (2008) yang berjudul hubungan emosional perawat terhadap kinerja perawat di RSI Muhammadiyah Bandung. Hasil penelitian tersebut menyatakan ada hubungan antara emosional perawat dengan kinerja perawat dan menyatakan bahwa semakin bertambah tua maka kecenderungan perawat untuk berperilaku positif lebih besar, terutama untuk perawat dengan usia di atas 40 tahun, sehingga semakin bertambah usia maka makin bertambah pula kemampuan seseorang dalam mengambil keputusan, berpikir secara rasional, semakin bijaksana, mampu mengendalikan emosi dan toleran terhadap pandangan orang lain.

Faktor yang menyebabkan caring perawat di ruang ICU (Intensive Care Unit) RSUD RAA Soewondo Pati ada yang kurang karena masa kerja yang belum terlalu lama sehingga perawat belum terlalu banyak pengalaman dalam melayani pasien di ICU. Hal ini dukung jurnal penelitian Purbadi \& Sofiana (2008) yang berjudul Analisis Faktor Lingkungan dan Individu yang Berpengaruh Terhadap Peningkatan Kinerja Perawat (Studi Kasus Instalasi Rawat Inap Rumah Sakit Annisa Cikarang). Hasil penelitian menunjukkan bahwa lama kerja di atas 5 tahun membuat perawat mempunyai pengetahuan yang lebih baik terhadap pekerjaannya sehingga dapat mengambil keputusan yang lebih cermat terkait pekerjaannya tersebut (Purbadi \& Sofiana, 2006).

\section{SIMPULAN DAN SARAN}

\section{Simpulan}

Diketahui bahwa jenis kelamin perawat di ruang ICU (Intensive Care Unit) RSUD RAA Soewondo Pati Tahun 2017 sebagian besar perempuan sebanyak 13 orang dan yang laki laki sebanyak 7 orang. Pendidikan perawat di ruang ICU (Intensive Care Unit) RSUD RAA Soewondo Pati Tahun 2017 sebagian besar D3 keperawatan sebanyak 16 orang $(80 \%)$ sedangkan pendidikan S1 keperawatan sebanyak 1 orang (5\%). Ners sebanyak 3 orang (15\%). Dan masa kerja perawat di ruang ICU (Intensive Care Unit) RSUD RAA Soewondo Pati Tahun 2017 sebagian besar mempunyai masa kerja 5-8 tahun sebanyak 15 orang (75\%) dan paling sediki tmempunyai masa kerja $\geq 9$ tahun sebanak 2 orang (10\%).

Caring perawat di ruang ICU (Intensive Care Unit) RSUD .RAA. Soewondo Pati Tahun 2017 sebagian besar baik sebanyak 15 orang (75\%) perawat yang caring nya cukup sebanyak 3 orang (15\%) sedangkan yang caring perawat kurang sebanyak 2 orang (10\%). 


\section{Saran}

1. Bagi Kepala Ruang

Diharapkan perlu meningkatkan fungsi pengarahan dan pengawasan terhadap penerapan prilaku caring perawat dalam pemberian pelayanan keperaatan kepada pasien.

2. Bagi Institusi Pendidikan

Diharapkan penelitian ini dapat berguna bagi para mahasiwa yang sedang mencari referensi untukmelakukanpenelitianselanjutnya

3. Bagi Peneliti

Diharapkan dari hasil penelitian peneliti dapat menerapkan ilmu pengetahuan yang didapat untuk diaplikasikan di lapangan terutama untuk caring pada pasien.

4. Bagi Responden/ Perawat

Diharapkan semua perawat mengerti akan pentingnya caring terhadap pasien yang berguna untuk memotivasi pasien agar cepat sembuh.

5. Bagi peneliti selanjutnya

Diharapkan peneliti selanjutnya dapat mengembangkan penelitian mengenai caring perawat dengan menambah variabel.

\section{DAFTAR PUSTAKA}

Ardiana.2010, Hubungan Kecerdasan Emosional Perawat Dengan Prilaku Caring Perawat Pelaksana Menurut Persepsi Pasien di Ruang Rawat Inap RSU H. Koesnadi Bondowoso, FIK UI.

Asmadi.2008, Konsep Dasar Keperawatan, Buku Kedokteran.Jakarta : ECG

Kemenkes RI, Kantor Derektorat Jendral Bina Upaya Kesehatan, ditetapkan di Jakarta.26 Juli 2010.

Listianingsih. 2012. Hubungan Prilaku Caring Perawat Dengan Kepuasan Pasian False Emergency di UGD Rumah Sakit Kawaluyan. Jurnal keperawatan

Natasia, Andriani dkk.2014. Hubungan Antara Faktor Motivasi dan Supervisi dengan Kinerja Perawat dalam Pendokumentasian Discharge Planning di RSUD Gambiran Kota Kediri.DinkesKabupaten Malang.

Marrison \& Burnard. 2009. Caring dan Communicating, Hubungan Interpersonal dalam Keperawatan, Buku Kedokteran. Jakarta : ECG.

Musliha, 2010. Keperawatan Gawat Darurat. Jakarta : Nuhamedika.

Purbadi\&Sofiana, 2006.Analisis Faktor Lingkungan dan Individu yang Mempengaruhi Terhadap Kinerja Perawat (Studi Kasus Instalasi Rawat Inap Rumah Sakit Annisa Cikarang).Institut Teknologi Bandung.

Saryono. 2010. Metodologi Penelitian Kesehatan Yogyakarta : Mitra Cendekia Press.

Suhartati.2008. Metode Penelitian Kualitatif Kuantitatif dan RND.Bandung : Alfabeta.

Sunardi.2014. Analisis Prilaku Caring Perawat Pelaksana, Jurnal Keperawatan vol 5, ISSN : 2086-3071.

Wawan \& Dewi. 2010. Teori Dan Pengukuran Pengetahuan, Sikap dan Prilaku Manusia. Yogyakarta: Nuha Medika

Wicaksonodan Prawesti.2012 Kiat Keperawatan (caring) Dalam Meningkatkan Mutu Asuhan Keperawatan. Jurnal STIKES. 


\section{PEDOMAN PENULISAN NASKAH \\ JURNAL KEPERAWATAN DAN KESEHATAN MASYARAKAT \\ "CENDEKIA UTAMA"}

\section{TUJUAN PENULISAN NASKAH}

Penerbitan Jurnal Ilmiah "Cendekia Utama" ditujukan untuk memberikan informasi hasil- hasil penelitian dalam bidang keperawatan dan kesehatan masyarakat.

\section{JENIS NASKAH}

Naskah yang diajukan untuk diterbitkan dapat berupa: penelitian, tinjauan kasus, dan tinjauan pustaka/literatur. Naskah merupakan karya ilmiah asli dalam lima tahun terakhir dan belum pernah dipublikasikan sebelumnya. Ditulis dalam bentuk baku (MS Word) dan gaya bahasa ilmiah, tidak kurang dari 20 halaman, tulisan times new roman ukuran 12 font, ketikan 1spasi,jaraktepi3 $\mathrm{cm}$,danukurankertas A4.Naskahmenggunakanbahasa Indonesia baku, setiap kata asing diusahakan dicari padanannya dalam bahasa Indonesia baku, kecuali jika tidak ada, tetap dituliskan dalam bahasa aslinya dengan ditulis italic. Naskahyangtelahditerbitkanmenjadihakmilikredaksidannaskahtidakbolehditerbitk an dalam bentuk apapun tanpa persetujuan redaksi. Pernyataan dalam naskah sepenuhnya menjadi tanggung jawab penulis.

\section{FORMAT PENULISAN NASKAH}

Naskah diserahkan dalam bentuk softfile dan print-out 2 eksemplar. Naskah disusun sesuaiformatbakuterdiridari:JudulNaskah,NamaPenulis,Abstrak,LatarBelakan g, Metode, Hasil dan Pembahasan, Simpulan dan Saran, DaftarPustaka.

\section{Judul Naskah}

Judul ditulis secara jelas dan singkat dalam bahasa Indonesia yang menggambarkan isi pokok/variabel, maksimum 20 kata. Judul diketik dengan huruf Book Antique, ukuranfont 13, bold UPPERCASE, center, jarak 1spasi.

\section{Nama Penulis}

Meliputi nama lengkap penulis utama tanpa gelar dan anggota (jika ada), disertai nama institusi/instansi, alamat institusi/instansi, kode pos, PO Box, e-mailpenulis, dan no telp. Data Penulis diketik dengan huruf Times New Roman, ukuran font 11, center, jarak 1spasi Abstrak

Ditulis dalam bahasa inggris dan bahasa Indonesia, dibatasi 250-300 kata dalam satu paragraf, bersifat utuh dan mandiri.Tidak boleh ada referensi. Abstrak terdiri dari: latar belakang, tujuan, metode, hasil analisa statistik, dan kesimpulan. Disertai kata kunci/ keywords.

Abstrak dalam Bahasa Indonesia diketik dengan huruf Times New Roman, ukuran font 
jarak1spasi.AbstrakBahasaInggrisdiketikdenganhurufTimesNewRoman, ukuranfont 11, italic, jarak1spasi.

\section{Latar Belakang}

Berisi informasi secara sistematis/urut tentang: masalah penelitian, skala masalah, kronologis masalah, dan konsep solusiyang disajikan secara ringkas dan jelas.

\section{Bahan dan Metode Penelitian}

Berisi tentang: jenis penelitian, desain, populasi, jumlah sampel, teknik sampling, karakteristik responden, waktu dan tempat penelitian, instrumen yang digunakan, serta uji analisis statistik yang digunakan disajikan dengan jelas.

\section{Hasil dan Pembahasan}

Hasil penelitian hendaknya disajikan secara berkesinambungan dari mulai hasil penelitian

utamahinggahasilpenunjangyangdilangkapidenganpembahasan.Hasildanpembahas an dapat dibuat dalam suatu bagian yang sama atau terpisah. Jika ada penemuanbaru, hendaknya tegas dikemukakan dalam pembahasan. Nama tabel/diagram/gambar/skema,

isibesertaketerangannyaditulisdalambahasaIndonesiadandiberinomorsesuaidengan urutan penyebutan teks. Satuan pengukuran yang digunakan dalam naskah hendaknya mengikuti sistem internasional yang berlaku.

\section{Simpulan dan Saran}

Kesimpulan hasil penelitian dikemukakan secara jelas. Saran dicantumkan setelah kesimpulan yang disajikan secara teoritis dan secara praktis yang dapat dimanfaatkan langsung oleh masyarakat.

\section{Ucapan Terima Kasih (apabila ada)}

Apabila penelitian ini disponsori oleh pihak penyandang dana tertentu, misalnya hasil penelitian yang disponsori oleh DP2M DIKTI, DINKES, dsb.

\section{Daftar Pustaka}

Sumber pustaka yang dikutip meliputi: jurnal ilmiah, skripsi, tesis, disertasi, dan sumber pustaka lain yang harus dicantumkan dalam daftar pustaka. Sumber pustaka disusun berdasarkan sistem Harvard. Jumlah acuan minimal 10 pustaka (diutamakan sumber pustaka dari jurnal ilmiah yang uptodate 10 tahun sebelumnya). Nama pengarang diawali dengan nama belakang dan diikuti dengan singkatan nama di depannya. Tanda "\&" dapat digunakan dalam menuliskan nama-nama pengarang, selama penggunaannya bersifat konsisten. Cantumkan semua penulis bila tidak lebih dari 6 orang. Bila lebih dari 6 orang, tulis nama 6 penulis pertama dan selanjutnya dkk.

Daftar Pustaka diketik dengan huruf Times New Roman, ukuran font 12, jarak 1 spasi.

\section{TATA CARA PENULISAN NASKAH}

Anak Judul : Jenis huruf Times New Roman, ukuran font 12, Bold UPPERCASE

Sub Judul : Jenis huruf Times New Roman, ukuran font 12, Bold, Italic

Kutipan : Jenis huruf Times New Roman, ukuran font 10, italic

Tabel: Setiap tabel harus diketik dengan spasi 1, font11 atau disesuaikan. Nomor tabel diurutkan sesuai dengan urutan penyebutan dalam teks (penulisan nomor 
tidak memakai tanda baca titik “.”). Tabel diberi judul dan subjudul secara singkat. Judul tabel ditulis diatas tabel. Judul tabel ditulis dengan huruf Times New Roman dengan font 11, bold (awal kalimat huruf besar) dengan jarak 1 spasi, center. Antara judul tabel dan tabel diberi jarak 1 spasi. Bila terdapat keterangan tabel, ditulis dengan font 10, spasi 1, dengan jarak antara tabel dan keterangan tabel 1 spasi. Kolom didalam tabel tanpa garis vertical. Penjelasan semua singkatan tidak baku pada tabel ditempatkan pada catatan kaki.

Gambar : Judul gambar diletakkan di bawah gambar. Gambar harus diberi nomor urut sesuai dengan pemunculan dalam teks. Grafik maupun diagram dianggap sebagai gambar. Latar belakang grafik maupun diagram polos. Gambar ditampilkan dalam bentuk 2 dimensi. Judul gambar ditulis dengan huruf Times New Roman dengan font 11, bold (pada tulisan "gambar 1"), awal kalimat huruf besar, dengan jarak 1 spasi, center Bila terdapat keterangan gambar, dituliskan setelah judul gambar.

Rumus : ditulis menggunakan Mathematical Equation, center

Perujukan : pada teks menggunakan aturan (penulis, tahun)

\section{Contoh Penulisan Daftar Pustaka :}

\section{Bersumber dari buku atau monograf lainnya}

i. Penulisan Pustaka Jika ada Satu penulis, dua penulis atau lebih :

Sciortino, R. (2007) Menuju Kesehatan Madani. Yogyakarta: Gadjah Mada University Press.

Shortell, S. M. \& Kaluzny A. D. (1997) Essential of health care management. New York: Delmar Publishers.

Cheek, J., Doskatsch, I., Hill, P. \& Walsh, L. (1995) Finding out: information literacy for the 21st century. South Melbourne: MacMillan Education Ausralia.

ii. Editor atau penyusun sebagai penulis:

Spence, B. Ed. (1993) Secondary school management in the 1990s: challengeand change. Aspects of education series, 48. London: Independent Publishers.

Robinson, W.F.\&Huxtable,C.R.R. eds.(1998) Clinicopathologic principles for veterinary medicine. Cambridge: Cambridge University Press.

iii. Penulis dan editor:

Breedlove, G.K.\&Schorfeide, A.M.(2001)Adolescent pregnancy.2nded.

Wiecrozek, R.R.ed.White Plains (NY): March of Dimes Education Services.

iv. Institusi, perusahaan, atau organisasi sebagai penulis:

Depkes Republik Indonesia (2004) Sistem kesehatan nasional. Jakarta: Depkes.

2. Salah satu tulisan yang dikutip berada dalam buku yang berisi kumpulan berbagai tulisan. 
Porter, M.A. (1993) The modification of method in researching postgraduate education. In: Burgess, R.G.ed. The research process in educational settings: ten case studies. London: Falmer Press, pp.35-47.

3. Referensi kedua yaitu buku yang dikutip atau disitasi berada di dalam buku yang lain

Confederation of British Industry (1989) Towards a skills revolution: a youth charter. London: CBI. Quoted in: Bluck, R., Hilton, A., \& Noon, P. (1994) Information skills in academic libraries: a teaching and learning role i higher education. SEDA Paper 82. Birmingham: Staff and Educational Development Association, p.39.

\section{Prosiding Seminar atau Pertemuan}

ERGOB Conference on Sugar Substitutes, 1978. Geneva, (1979). Health and Sugar Substitutes: proceedings of the ERGOB conference on sugar substitutes, Guggenheim, B. Ed. London: Basel.

\section{Laporan Ilmiah atau Laporan Teknis}

Yen, G.G (Oklahoma State University, School of Electrical and Computer Engineering, Stillwater, OK). (2002, Feb). Health monitoring on vibration signatures. Final Report. Arlington (VA): Air Force Office of AFRLSRBLTR020123. Contract No.: F496209810049

6. Karya Ilmiah, Skripsi, Thesis, atau Desertasi

Martoni (2007) Fungsi Manajemen Puskesmas dan Partisipasi Masyarakat DalamKegiatan Posyandu di Kota Jambi. Tesis, Universitas Gadjah Mada.

\section{Artikel jurnal}

a. Artikel jurnal standard

Sopacua, E. \&Handayani,L.(2008) Potret Pelaksanaan Revitalisasi Puskesmas. Jurnal Manajemen Pelayanan Kesehatan, 11: 27-31.

b. Artikel yang tidak ada nama penulis

How dangerous is obesity? (1977) British Medical Journal, No. 6069, 28 April, p. 1115.

c. Organisasi sebagai penulis

Diabetes Prevention Program Research Group. (2002) Hypertension, insulin, and proinsulin in participants with impaired glucose tolerance. Hypertension, 40 (5), pp. 679-86

d. Artikel Koran

Sadli,M.(2005) Akan timbul krisis atau resesi?. Kompas, 9 November, hal.6.

\section{Naskah yang tidak di publikasi}

Tian,D.,Araki,H., Stahl, E., Bergelson, J., \& Kreitman, M. (2002) Signature of balancing selection in Arabidopsis. Proc Natl Acad Sci USA. In Press.

9. Buku-buku elektronik (e-book)

Dronke, P. (1968) Medieval Latin and the rise of European love- lyric [Internet].Oxford: Oxford University Press. Available from: netLibraryhttp://www.netlibrary.com/ urlapi.asp?action=summary $\& v=1 \&$ bookid=22981 [Accessed 6 March 2001] 


\section{Artikel jurnal elektronik}

Cotter, J. (1999) Asset revelations and debt contracting. Abacus [Internet], October, 35 (5) pp. 268-285. Available from: http://www.ingenta.com [Accessed 19

November 2001].

\section{Web pages}

Rowett, S.(1998)Higher Education for capability: automous learning for life and work[Internet],Higher Education for capability.Available from:http://www.lle. mdx.ac.uk[Accessed10September2001]

\section{Websites}

Program studi S2 Ilmu Kesehatan Masyarakat UGM. (2005) Program studi S2 Ilmu Kesehatan Masyarakat UGM [Internet]. Yogyakarta: S2 IKM

UGM. Tersedia dalam: http://ph-ugm.org [Accessed 16 September2009].

13. Email

Brack, E.V. (1996) Computing and short courses. LIS-LINK 2 May 1996

[Internetdiscussionlist].Availablefrommailbase@mailbase.ac.uk[Acc essed 15 April1997]. 